\section{Conference of the National Union of Teachers}

A Bookrex has been issued containing eight of the addresses delivered at sectional meetings of the Annual Conference of the National Union of Teachers held in Margate in June last (London: National Union of Teachers, 6d. net). "Exemptions and Beneficial Employment", in connexion with the Factory Act, 1937, which has just come into operation, was the subject of addresses by Major Evan Davies, Mrs. Alderman Wainwright and Mr. F. A. Ring, who all foresee considerable difficulties for the authorities and administrators who have been given the task of working the Act. The subject of handicraft in schools was dealt with by Mr. F. Potter, who considers that the prestige of handicrafts and of handicraft teachers never stood higher and continues to increase. He expressed the hope that, in the future, room would be found for promotion to headships in the newer senior schools of the really educated and skilled craftsman.

\section{London Lectures for Teachers}

THE L.C.C. Handbook for 1938-39 of lectures and classes for teachers gives particulars of 114 courses distributed over a wide field. Nearly half (52) relate to art and crafts, music and physical education, 19 are listed under 'pedagogy' and 7 under 'science'. Among what may be called the 'star turns' are lectures on food production by Sir John Russell, on recent advances in physics by Prof. J. D. Cockroft and Prof. E. K. Rideal, on vitamins, hormones and stimulating substances by Dr. J. Needham and on astronomy by Sir Arthur Eddington. There are three courses which should prove useful on how to make use of museums (British, Victoria and Albert and London). Four deal with the important, but too often neglected, subjects of speech-training, speech therapy and backwardness in reading. Another often neglected subject will be dealt with under the title "Thinking and Writing" by Mr. R. W. Jepson at Mercers' School on lines designed to help in the training of children of 11-14 years of age to use language "as a medium for clear and exact thought and expression-to understand its structure and working and the meanings it conveys, to realize its potentialities for enlightenment and confusion, and to apply the knowledge thus gained to their own writing". The equally neglected science and art of cookery find no place in the programme except by implication in the syllabus of a course on domestic subjects.

\section{Australian Journal of Science}

THE first number of the Australian Journal of Science has recently been issued. This journal is published by the Australian National Research Council under the auspices of the Australian and New Zealand Association for the Advancement of Science, and six numbers will appear each year. Scientific work in Australia has developed greatly in recent years, and the need for a means of publishing short advance summaries of research has become more and more apparent. The new journal is designed to satisfy this need and also, in line with other well- known scientific journals, to publish reviews, news and views, reports of proceedings of various scientific institutes and correspondence. The first number now to hand augurs well for the success of the project. The substance of the inaugural lecture by Prof. Eric Ashby, newly appointed professor of botany in the University of Sydney, on "The Place of Biology in Australian Education" is purposely provocative and should be read with interest and profit by all biologists, but especially by those responsible in some way or another for the teaching of biology in Australia. Sir Douglas Mawson has an interesting short article on research in the antarctic. Australian Science Abstracts are in future to be incorporated in the Australian Journal of Science as a supplement. Subscription for the Journal is $12 s$. for one year. Further information can be obtained from the Australian National Research Council, Science House, 157-161 Gloucester Street, Sydney, N.S.W.

\section{Institution of Civil Engineers: Awards}

THE following awards of the Institution of Civil Engineers have been made for session 1937-38: Telford Premiums to Sir George Lee, M. G. J. McHaffie, jointly to W. C. Parker and Hubert Clarke, jointly to William Hudson and J. K. Hunter, George Ellson, jointly to F. J. Buckton and H. J. Fereday, R. W. Mountain, W. A. Tookey, F. C. Vokes, Prof. A. H. Gibson, J. F. Hay, Frank Fancutt, T. H. Seaton; Coopers Hill War Memorial Prize to William Hawthorne and F. H. Williams (jointly); Trevithick Premium to R. G. Knight; Manby Premium to Dr. H. J. Gough and W. A. Wood (jointly); Indian Premium to M. R. Atkins and D. H. Remfry (jointly). For papers published in the Journal without oral discussion : Telford Premiums to Prof. F. C. Lea and J. G. Whitman (jointly); Dr. C. F. Colebrook and Prof. C. M. White (jointly), Herbert Addison, Thomas Donkin; Trevithick Premium to G. C. Blofield; Crampton Prizes to J. R. Daymond, Serge Leliavsky. For students' papers read in London or at meetings of local associations: James Forrest Medal and a Miller Prize to John Hayes; Miller Prizes to I. S. Chisholm, A. R. Collins, A. L. Arnold, E. F. Humphries, Jack Mercer, J. M. P. Hooley.

\section{Australian and New Zealand Association}

THE twenty-fourth meeting of the Australian and New Zealand Association for the Advancement of Science is to be held at Canberra on January 11-18, 1939, under the presidency of Prof. Emest Scott, emeritus professor of history in the University of Melbourne. This meeting is regarded as the jubilee meeting of the Association, the first meeting having been held in Sydney in August 1888 under the presidency of the late Mr. H. C. Russell. Six men of science from Great Britain have accepted invitations to attend this meeting : they are Prof. F. T. Brooks, Sir John Flett, Dr. Julian Huxley, Sir John Russell, Dr. N. V. Sidgwick and Mr. H. G. Wells. It is hoped that the practice thus introduced of welcoming a group of scientific workers from overseas will be continued at all future biennial meetings. The presidents of the sections are as follows: Section A 